\title{
Early Warning and Response: Why the International Community Failed to Prevent the Genocide
}

HOWARD ADELMAN, York University, Toronto, and ASTRI SUHRKE, Christian Michelsen Institute, Norway

'Western leadership ... has proclaimed moral indifference to be its decent Christian right' John le Carré (1995, p. 213).

The enormity of the genocide in Rwanda demands that it be subjected to searching enquiry and that members of the international community, collectively and individually, examine their own roles in the event.

This paper draws extensively on Study II of the Joint Evaluation, and examines the effectiveness of international monitoring (early warning) and management of the Rwanda conflict. It is not intended to explore all the factors which together contributed to the genocide that were or might have been amenable to modification by the international community. The focus is on warning and response beginning with the start of the civil war in 1990, and culminating in an analysis of the international response to the genocide in April-June 1994.

\section{INTRODUCTION}

Evaluators and historians have the luxury of hindsight to criticise actions and inactions that subsequently appear inappropriate. Any search for lessons from the tragedy must, however, avoid retrospective speculation. Decision-makers were faced with often confusing signals, numerous competing demands for their attention and limitations on the resources at their disposal. Critical policy theory was used by the evaluators to weigh the formulation and execution of policies against their stated objectives as well as accepted international norms for the behaviour of states and organisations. This paper, like the study before it, is based on a number of sub-studies, secondary sources as well as considerable primary data collected through interviews and document searches in the UN system, the NGO community and visits to national capitals in Europe, North America and Africa.

\section{IMPLICATIONS OF THE EVENTS OF 1959-62}

Having administered the country through the Tutsi aristocracy for four decades, the Belgian colonial authorities ${ }^{1}$ turned their support towards the majority Hutu in the 
late-1950s - a switch driven by the realisation of the inevitability of the de-colonisation process, the logic of democratic rule and Belgian resentment that the strongest calls for independence were coming from among the favoured Tutsi class. After the so-called 'peasant revolt' of Hutu against the Tutsi ruling class in 1959, during which thousands of Tutsi were killed and tens of thousands fled the country, the colonial authorities installed a military-led administration and took the opportunity of placing Hutu appointees in chief and sub-chief posts vacated by Tutsi.

The table-turning process was carried forward by the overwhelming victory of the PARMEHUTU party in the local elections of 1960, the parliamentary elections of 1961 and the referendum of 1961 which saw the massive rejection of the monarchy in favour of a republican system of government. The process was accompanied by sporadic fighting between Tutsi and Hutu, and the persecution of Tutsi as the Hutu increased their grip on power. By late 1963 , at least 130,000 Tutsi had sought refuge in the neighbouring Belgian Congo (now Zaire), Burundi, Uganda and Tangyanika (now Tanzania). Some estimates of the numbers involved have been much higher.

The speed of the switch in the configuration of Rwandan politics, and an awareness that it could leave the country with an embittered Tutsi minority, provoked considerable criticism of Belgium's policy in the UN General Assembly, ${ }^{2}$ and repeated calls for the encouragement of a process of national reconciliation. The Belgian administration rejected the calls, and sought to head off further UN 'tinkering' by organising a de facto declaration of independence in early 1961 by the acclamation of over 3,000 bourgemestres and municipal councillors. The country achieved formal independence in July 1962.

A report by the UN Trusteeship Commission in early 1961 noted:
The developments of these last eighteen months have brought about the racial dictatorship of one party. ... An oppressive system has been replaced by another one. ... It is quite possible that some day we will witness violent reactions on the part of the Tutsi (cited in Prunier, 1995).

By 1961, armed incursions into Rwanda by Tutsi refugees had begun; these continued until 1967. The main base for these initial attacks was Burundi which continued to be governed by a Tutsi minority. One attack into the Bugasera area in late 1963 came quite close to reaching Kigali, but mostly the attacks were neither well organised nor adequately resourced. Inside Rwanda, which had become a de facto single-party state, Tutsi were increasingly excluded from public life and armed incursions were not only repulsed, but bouts of anti-Tutsi violence flared; an estimated 10,000 Tutsi were slaughtered in the Bugasera area following the 1963 incursion (Prunier, 1995). Another wave of anti-Tutsi violence took place in 1972-3 fuelled by events in Burundi where tens of thousands of Hutu had been massacred by the Tutsi minority in a bid to remain in power.

Such repression and violence swelled the number of Rwandan Tutsi living in exile in neighbouring countries. When allowance is made for natural population growth among this group, by the 1990s the total number of refugees was in the order of 600,000-700,000 (Prunier, 1995), although the political and propaganda significance of such estimates and the difficulties of accurately measuring such a widely distributed population makes any figure a matter of dispute. With the overthrow of the Hutu PARMEHUTU dictatorship and its replacement by a dictatorship from the north-west under Habyarimana in 1973, the persecution of, though not the discrimination against, Tutsi stopped. Habyarimana, however, steadfastly refused to allow the Tutsi refugees to return. 
In 1981 a small number of the Tutsi refugees in Uganda joined one of the groups opposed to the regime of President Obote. The group was led by Yoweri Museveni, who was related (though distantly) to a Rwandan Tutsi family. As the guerilla activities increased in intensity Museveni's links with Rwandan Tutsi led to increasing hostility between Ugandan officials and people towards the Tutsi living there in exile. This in turn led to more Tutsi joining what was now Museveni's National Resistance Army (NRA), which eventually succeeded in ousting the Obote regime in 1986. By then a number of Tutsi had risen to very prominent positions within the NRA.

Once in power, Museveni's position depended upon accommodating the various factions within the country who resented the connection with the Rwandan Tutsi. Seeing the direction of Ugandan politics, the Rwandan Tutsi community in Uganda became more determined to return to their own country. In 1988, the Rwandan Patriotic Front (RPF), which also included some Hutu opposed to the Habyarimana regime, was formally created in Kampala with the objective not just of ensuring the return of those Tutsi in exile, but changing the political regime in Rwanda. Within Rwanda the position of the government was weakened by a combination of deteriorating economic conditions (resulting from the dramatic decline in the international price of coffee, which was Rwanda's primary export) and opposition to regionally based, autocratic rule. Habyarimana was also coming under pressure from France and other donor countries to move away from the oneparty system by allowing new political parties to develop.

By failing to deal with the festering refugee problem before 1990, both the Rwandan and the Ugandan governments, as well as the wider international community, set the stage for future con- flict. Although the issue of Rwandan refugees in Uganda defied easy solution, opportunities that had existed remained unexplored or were not aggressively pursued. With the exception of Tanzania, those regional states that were not indifferent were part of the problem, while more distant states showed little interest. UNHCR, overburdened and understaffed, lacked the political or economic leverage to help resolve the issue, which, at that time, seemed minor in any global scale of refugee problems.

\section{THE CIVIL WAR STARTS}

On 1 October 1990, a well-armed force of the military wing of the RPF invaded northern areas of Rwanda from Uganda. Much of the force was composed of Rwandan Tutsi soldiers from the Ugandan army and much of their armaments were reputedly stolen from Ugandan army stores. Though repulsed, the attack signalled the start of the civil war in Rwanda: a war which was used to increase the intensity of fear and hatred and raise the stakes of political survival.

The build-up of tension leading to the 1990 invasion by RPF forces was accompanied by many tell-tale signs, which were inadequately monitored. When the invasion was a fait accompli, however, it attracted considerable international concern and reaction, both in the region and in Europe. France and Zaire came to the aid of the Rwandan government. Other actors, including Belgium, the OAU and key regional states, initiated diplomatic efforts to defuse the conflict.

The initial diplomatic efforts eventually led to a series of peace talks, initiated and led by the OAU and Tanzania and held at Arusha in Tanzania. The process, begun in August 1992, received considerable international attention, and resulted in a comprehensive settlement, 
the Arusha Accords, signed in August 1993. The United Nations assumed formal responsibility for overseeing the implementation of the Arusha Accords, including the provision of peace-keepers, and in the process limited the role of the OAU and local African states. As a consequence, there was a disjuncture between the mediation and implementation phases which served to undermine the Accords.

From 1990 onwards, civil violence against the minority Tutsi community and critics of the Habyarimana regime had gradually escalated. Observers commonly linked the violence to the civil war, either as retaliatory measures or as warnings to the advancing RPF forces. However, two authoritative reports - one by an independent International Commission of Inquiry (FIDH, 1993), and another prepared for the UN Commission on Human Rights (UNCHR, 1994) - suggested a more radical and comprehensive design that foreshadowed events to come. Both reports determined that the killings were genocidal in nature and that existing authorities were deeply involved. As the war continued and the outlines of a peace formula took shape, persistent reports indicated that Hutu extremists were organising and arming themselves to de-rail the peace process and massacre 'internal enemies'. The creation of documented structures of violence (death squads, death lists, and later, hate propaganda inciting violence) provided warnings of a potential genocide.

The UN Commission on Human Rights took little notice of its own report. Except for pointed diplomatic protests by Belgium, the findings of the international human rights inquiry were mostly buried away in national ministries and the UN system. With the partial exception of Canada, no state observed the recommendation to impose strict human rights conditionality on aid transfers. Some states were indifferent; others were concerned but concluded that the ongoing democratisation process and the peace talks required their continued economic and political support, particularly since the peace agreement under negotiation would produce a new governmental structure that, it was hoped, would address human rights abuses. In this way, donors were held hostage to their own policies.

Human rights organisations and states were also at odds over the issue of arms supplies. In 1992 and 1993, the former recommended that states (France and Uganda were obvious targets) cut off all arms supplies to the parties in the conflict. France openly defended its role and the right of a sovereign state to support a beleaguered friendly government. Uganda denied any involvement in helping the rebel army, yet its territory constituted the rear base for the RPF forces.

Would aid conditionality and an international arms embargo in the 1990-93 period have defused the conflict and prevented the genocide? Effective use of human rights conditionality is difficult, requiring fine-tuned and timely intervention. Arguably, there were windows of opportunity, particularly in mid-1992, when more pressure could have been applied to the Habyarimana regime to deal with the extremist forces as well as the critical issue of impunity. Also military assistance (direct and indirect) to the Rwandan protagonists could have been calibrated better with the continuing peace process, particularly in dealing with the central issue of extremist forces who opposed the Arusha process and resultant Accords.

Though such speculations are debatable, firmer conclusions can be drawn about what did happen. By not standing firm on human rights conditionality, donors collectively sent the message that their priorities lay elsewhere. By permitting arms to reach the Rwandan protagonists, the possibilities for demilitarising 
the conflict were reduced. Arms supplies reinforced the determination of both parties to seek a military and forceful solution to a political conflict. They strengthened the RPF's ability to advance militarily. They permitted the government to equip and expand its armed forces as well as para-military units, both of which became involved in the genocide.

When, as a result of the Arusha process, the Hutu extremists were excluded from the key instruments of the transitional government and marginalised in the political process, alternative strategies were not developed to 'de-fang' those extremists. The UN force (UNAMIR) sent to oversee the implementation of the peace agreement was given a mandate tailored to a classic, minimalist peace-keeping operation. Yet the force faced a situation considered by many, including some of those who planned the operation, as dangerously unstable.

As the architects of the Arusha Accords had foreseen, conditions in Rwanda suggested a mandate with broad powers to protect civilians and seize arms caches. Further, the UN Security Council established a force that was structured and financed to satisfy a cost-conscious United States, increasingly unwilling to support UN peace-keeping, rather than to meet the needs on the ground. The force was inadequately supported (although relatively rapid given the normally cumbersome UN procedures), and only slowly deployed relative to the need for speed (considered essential to maintain the peace process). The operation had no flexibility to respond to changing circumstances, in particular those caused by the crisis in neighbouring Burundi in October 1993.

In the months immediately preceding the genocide, many additional signs indicated that the implementation of the Arusha Accords was faltering and that massive violence was being planned. The air was full of extremist rhetoric on radio, in public rallies and at official cocktail parties. There were assassinations and organised violence. Detailed intelligence reports were passed to New York and the Belgian military authorities by the unofficial UNAMIR intelligence unit documenting the military training of militias, hidden arms caches and plans for violent action. Unequivocal warnings reached the UN Secretariat on 11 January 1994 regarding a planned coup, an assault on the UN forces to drive them out, provocations to resume the civil war, and even detailed plans for carrying out genocidal killings in the capital. The cable was placed in a separate black-coloured file, designed to draw attention to the gravity of its content, and circulated to several departments in the UN Secretariat. However, senior officials in the Secretariat questioned the validity of the information and made no contingency plans for worst-case scenarios. Similar intelligence failures were evident at the state level, particularly in France and Belgium, both of which had a considerable capacity for overt and covert information gathering in Rwanda at the time.

Thus pieces of information were available that, if combined and analysed, would have permitted policy-makers to draw the conclusion that both political assassinations and genocide might occur, and that the scale would be different from past patterns $(1959-63$; 1991-3) of 'just' hundreds or thousands of victims. Yet this analysis was not done. Although some had available fragments of prescient and significant information, the enormity of the genocide took virtually all by surprise. The failure to anticipate planned and targeted mass murder was particularly significant given the political commitment and actual involvement of the $U N$ in Rwanda, the legal right and moral obligation to act to prevent genocide according to the Genocide Convention, and the enormous cost of a miscalculation. 
While mandated to help implement the peace agreement, the UN made no preparations to deal with a breakdown of the Accords, except to withdraw. Nor were there contingency preparations to deal with the plans to scuttle the Accords or the massive violence plotted by the extremists. Generally, the UN Secretariat interpreted UNAMIR's mandate and rules of engagement narrowly, and on several occasions denied the Force Commander permission to search for and seize arms caches. When developments in early 1994 further eroded the peace accords, the Secretary-General and the Security Council threatened to withdraw the UN force, hence strengthening the hands of the extremists. No member of the Security Council came forward to suggest a different course of action. On the contrary, the Council kept UNAMIR on a tight leash with only a three. months' authorisation, accompanied by admonitions of caution and emphasising the importance of cost-cutting.

\section{CRISIS AND RESPONSE: APRIL TO JUNE 1994}

In the months before the crisis struck, UNAMIR's presence contributed to a false sense of security in Rwanda. When events came to a head on 6 April, the UN collectively failed to respond. There was an absence of leadership at UN headquarters in New York. The SecretaryGeneral, travelling at a brisk pace through Europe, misread the nature of the conflict. The understaffed and overstretched Department of Peace-keeping Operations seemed paralysed. In the Security Council, the killing of 10 Belgian peacekeepers created a political surge to withdraw, although this was not recommended by UNAMIR's Force Commander nor by the African countries contributing troops. Information on the genocide under way was already available when the final decision was made to reduce the force drastically.

Once the direction and magnitude of the genocide became undeniable, the UN reversed itself and accepted an obligation to protect civilians. However, the realisation of this peace-keeping mission (UNAMIR II) was hampered by the unwillingness of key members to pay for or provide troops, and to match troops with equipment in an expeditious manner. The force was deployed only after the genocide and the civil war had run their course.

France's role in Rwanda was significant in its many contradictions. While warning the Security Council in early 1993 that massacres were a real possibility, France supported a regime that was deeply compromised by human rights violations. France urged the $U N$, rather than the OAU, to take the lead in monitoring and implementing the peace agreement, but subsequently did little to support UNAMIR I. Nor did France pledge support for UNAMIR II, even though the French Foreign Minister was the first cabinet member of a government holding a permanent seat on the Security Council to identify the massacres as genocide (16 May 1994). With the aid of some of its African ex-colonies, France subsequently undertook a unilateral intervention, Opération Turquoise, endorsed by a Chapter VII Security Council resolution. The action saved many lives and undoubtedly prevented an additional mass outflow of refugees from the south-west of Rwanda, but came very late: two and a half months after the genocide commenced and when the civil war was almost over. Further, because of France's historical role in the country, the intervention was open to misinterpretation, and did not serve to disarm the extremists or prevent suspected organisers of the genocide from escaping.

During the whole conflict, but especially after the coup on 6 April, the 
media, with some notable exceptions, failed to report accurately and adequately on a crime against humanity. This significantly contributed to international lack of interest in the genocide and the consequent inadequate response. Too many reports conformed to stereotypical notions of tribal violence and orgies of killing rather than to the power struggle and systematic slaughter of Hutu moderates as well as Tutsi that was under way. ${ }^{3}$

\section{FAILURES OF EARLY WARNING}

Whatever the failures in media coverage, prime responsibility for the failure to read the signals and respond adequately cannot be placed on the media. Why were the signals that were sent ignored? Why were they not translated into effective conflict management? The failure of early warning is attributable to many factors. The UN was poorly organised to collect and flag information about human rights violations and certainly genocide. There was a failure in both the UN system and the NGO community to link human rights reports to dynamic analyses of social conflict so as to provide strategic policy choices. There also existed an internal predisposition by a number of the key actors to deny the possibility of genocide because facing up to it would have required them to alter their course of action. The mesmerisation with the success of Arusha and the failure in Somalia together cast long shadows and distorted an objective analysis of Rwanda. The vast quantity of 'noise' from other crises worldwide preoccupied world leaders. The confusion between genocide as a legal term, referring primarily to an intent, and the popular association of genocide with massive murder in the order of hundreds of thousands, created confusion. Finally, a general desensitisation developed with respect to mass slaughters in Rwanda and Burundi, and the possibility of a massive genocide actually occurring seemed beyond belief. Major states with the capacity to monitor and anticipate the crisis were either not interested, or, if interested, were unwilling to undermine a friendly government. In such a situation, international organisations exist in part to pick up the slack, but neither the UN nor the OAU did so in the Rwanda case. The UN had poorly developed structures for systematically collecting and analysing information in a manner relevant to preventive diplomacy and conflict management. The newly formed inter-agency arrangement for humanitarian early warning (HEWS) was oriented mainly towards humanitarian operations; it was not equipped to detect or analyse political and military warning signals.

Within the Secretariat, information collection and policy analysis was divided among the Department of Political Affairs (DPA), the Department of Peace-keeping Operations (DPKO) and the Department of Humanitarian Affairs (DHA). There was also a disjuncture between information collection, analysis and the development of strategic policy options. Thus DPA was assigned the responsibility for monitoring events in the region, but not for developing related strategic policy options. One of the most significant sources for early warning, the UN human rights monitoring system, was not part of the informationgathering structure in the Secretariat and, arguably, became isolated from the decision-making process. In the field, the UN had no formal capacity for collecting intelligence; nevertheless, UNAMIR, through the initiatives of both the Canadian Force Commander and the Belgian Kigali-sector Commander, succeeded in running small, if irregular, intelligence operations. The other main organisation concerned, the OAU, had virtually no capacity at all for early warning data collection and policy analysis.

Yet the shortcomings of early warning 
in the Rwanda case go further. The issue is not better quantitative data or formal modelling. The UN lacked a system for drawing on existing information sources, in the region and outside, from specialists in state agencies, academic institutions, human rights monitoring agencies, and the various agencies of the UN itself. The UN lacked a specialised unit, without operational responsibilities, for analysing such information and translating that analysis into evolving strategic options that can be channelled directly to the Secretary-General.

Both the UN and NGOs failed to relate human rights monitoring to analysis of the development of social conflict and, hence, to assess the direction of events. When the UN became involved in a peace-keeping mission, the monitoring of political developments was not linked with contingency preparedness. Without contingency planning, the UN was left with a short time frame and few resources to respond to sudden changes in the situation. This point is critical for two reasons: even under the best of circumstances, it is impossible to pin-point specific future outcomes of complex social conflict; second, the absence of contingency planning limits both what the decision-makers will hear and the options they are willing to consider.

Despite the shortcomings of early warning, at the critical stage the relevant actors dealing with Rwanda knew that the situation was unstable and dangerous. Yet the sustained and careful attention so necessary to successful conflict management was lacking. In part, early action is problematic and preventive diplomacy is inherently difficult because outcomes are uncertain, reflecting the typical complexity of cause-and-effect relations in social and political conflict. Moreover, policy-makers who are continuously faced with actual crises are disinclined to pay attention to hypothetical ones, even though exper- ience tells us that 'prevention is better than cure'. The lack of international investment in early conflict regulation signified a more fundamental disinterest in Rwanda. The UN Security Council authorised only the most minimal peacekeeping force, and the Secretariat insisted that UNAMIR maintain a low profile. When the crisis struck, and it became clear that massive genocide was under way, there was still no effective international action.

\section{CONFLICT MANAGEMENT}

Throughout, some individual and collective actors did the most with the least under difficult or adverse circumstances. Human rights NGOs monitored the situation. Tanzania struggled to turn the Arusha process into effective preventive diplomacy. UNAMIR I tried to function proactively, despite tight reins before 6 April. Many remaining units, including the ICRC, bravely sought to save civilians once the killings started. This could not compensate, however, for the overall failure of the international community to attempt to prevent or stop the genocide, or its very inadequate efforts to mitigate it. In one sense, the inaction can be seen as a result of the propensity of states to be guided by narrow self-interest rather than moral obligations to uphold international norms of justice. However, this propensity has historically varied over time and place; its prominence in the Rwanda case, therefore, requires additional explanation.

No state involved in the conflict happened at the time to have the optimal combination of interest, capacity and neutrality that could have generated appropriate early warnings and translated them into conflict-mitigation strategies. More fundamentally, the Rwanda conflict occurred in a period when the United Nations was acting in an expansive yet highly selective fashion, reflecting a struc- 
tural mismatch between the responsibilities of international institutions and interests of states in the post-Cold War world.

Revitalised by the end of the Cold War, the UN in the 1990 s rapidly expanded its peace-keeping operations throughout the world. Rwanda was added to the list in October 1993. The framework for peace-keeping was, however, set by the distribution of power in the Security Council, which represented the world as it was half a century ago. Apart from France, the major powers on the Council were uninterested in a small Central African country that was marginal to their economic or political concerns and peripheral to international strategic rivalries. By their power of veto and finances, the Permanent Five controlled the peace-keeping and enforcement operations of the UN. The only state with a demonstrated ability to energise the Council in a crisis, the United States, was haunted by memories of Somalia and determined not to get involved in another African conflict. It was also preoccupied with crises elsewhere, especially in Bosnia and Haiti. The lack of interest in Rwanda on the part of the major Western states left France to define a large part of the policy field; the result was to magnify the consequences, negative as well as positive, of unilateralism.

Within the UN system as a whole, there was no locus for assessing key policy questions. How, for instance, can the democratisation process be promoted without exacerbating ethnic and regional tensions or creating excuses for human rights violations? How are extremists to be controlled? Moreover, there was too little effort at policy co-ordination when opportunities appeared.

The rationale for UN peace-keeping is that it provides a neutral force, independent of partisan interest. However, partisan interests can provide motivation and energy to be directed at a problem when a commitment to conflict resolution per se is lacking. This is the conundrum. Without either kind of interest, the UN as a collective actor was unable to mount an adequate peace-keeping force expeditiously and cut through the Byzantine problems endemic to UN peace-keeping. The mix-and-match system of deployment was slow and inadequate. Lacking a powerful patron in the Security Council, the Rwandan operation was subject to cumbersome and bureaucratic procedures that involved delays and inflexibility, and gave insufficient autonomy to the leadership in the field.

The international community might have responded better had the early warning systems generated a clearer anticipation of forthcoming events. On the other hand, conflict management is a function of interest and capacity, not only to ensuring that information is collected and communicated, but to react. In this respect, regionalism appears as a critical and positive force that was not sufficiently recognised or utilised. Structures of conflict resolution and peace-keeping could have been strengthened by more involvement of regional and sub-regional actors (the $\mathrm{OAU}$ and the sub-regional grouping of the states in the Great Lakes area) in the decision and management structures. After all, these actors had definite interests in the conflict and a critical stake in the outcome. Strengthening regional mechanisms for conflict resolution and peacekeeping will require financial support from richer states since most of the world's conflicts occur in regions where the parties have the fewest resources to deal with them. The consequence of these cumulative fault lines in the international system was an inability to stop or significantly mitigate a genocide of immense proportions.

\section{Notes}

1. The area which now forms Rwanda and Burundi was administered by German 
colonial authorities based in Dar-es-Salaam between 1899 and 1916. Belgium occupied the area during the First World War and subsequently administered the territories under mandates first of the League of Nations and subsequently of the UN.

2. In part such criticisms were influenced by the Eastern Bloc and Non-aligned view that the Tutsi political parties represented the most effective and radical opposition to Belgian colonialism.

3. On 12 April, for instance, the New York Times stated that the Hutu Prime Minister Agathe Uwilingiyimana who was killed by troops and militia on 7 April, in the same attack which resulted in killing of 10 Belgian soldiers serving in UNAMIR, was a Tutsi in an apparent attempt to mould reality to the notion that the events were simply Hutu versus Tutsi.

\section{References}

Fédération International Des Droits De l'Homme (FIDH)(1993) Rapport de la commission internationale d'enquête sur les violations des droits de l'homme au Rwanda depuis le 1er Octobre 1990. Paris, New York, Washington, London, Ouagadougou, Montreal.

Le Carré, J. (1995) Our Game. Hodder and Stoughton, London.

Prunier, G. (1995) The Rwanda Crisis: History of a Genocide 1959-1994. Hurst \& Company, London.

United Nations Commission on Human Rights (UNHCR)(1994) Report on the Situation of Human Rights in Rwanda. Addendum E/CN,4/1994/7/Add 1, 11 August 1993.

Address for correspondence: Centre for Refugee Studies, York University, 4700 Keele Street, North York, Ontario, Canada M3V 1 P3. 